\title{
Results of a pharmacoeconomic analysis of the rationality of the use of acute myeloid leukemia chemotherapy regimens with the use of various doses of cytarabine
}

\author{
Hanna Panfilova ${ }^{2}$, Anastasiya Goncharova ${ }^{1}$, Iuliia Korzh $^{2}$, Irina Zhirova ${ }^{1}$, Oksana Tsurikova ${ }^{3}$, and Natalia Bezuglaia ${ }^{*}$ \\ ${ }^{1}$ Belgorod State National Research University Belgorod, Russia \\ ${ }^{2}$ Dept. of Social Pharmacy, National University of Pharmacy, Kharkiv, Ukraine \\ ${ }^{3}$ Dept. of Pharmaceutical Marketing and Management National University of Pharmacy, Kharkiv, Ukraine,
}

\begin{abstract}
A pharmacoeconomic study of the rationality of the use of various chemotherapy regimens ("7 +3 " scheme) in the treatment of patients with acute forms of myeloid leukemia has been carried out. The use of the chemotherapy regimen " $7+3$ " with $200 \mathrm{mg} / \mathrm{m}^{2} /$ per day dosage of cytarabine on 1-7 days allows to achieve a unit of treatment efficacy at a lower cost (CEA $=19.22$ US $\$$ / per unit of efficacy), compared with another dosage of cytarabine that was two times less, i.e., $100 \mathrm{mg} / \mathrm{m}^{2} /$ day at the same period (CEA $=$ US $\$ 20.18 /$ unit of effectiveness). The presented research results can be used in the formation of programs for the rational use of limited resources in the purchase of anticancer drugs for hematological cancer patients, as well as in the development of schemes for providing them with effective medical care in a hospital setting.
\end{abstract}

\section{Introduction}

According to the World Health Organization, leukemia occupies a leading position in the morbidity structure of the human lymphoid and hematopoietic systems [1-3]. Specialists are particularly concerned about the fact that leukemias occupy the first positions in the structure of morbidity and mortality from malignant pathologies among people under the age of 17 years [4-6]. It is a wellknown fact, that this category of the population forms the socio-economic potential of any country, and the loss of patients under the age of 17 is an important demographic problem in any state and in society as a whole [7-8]. Therefore, the development of new approaches in the treatment of acute leukemia, in particular myeloid leukemia, is of both medical and socio-economic importance [9-10]. The basic principles of treatment of acute leukemia were formulated thanks to the achievements of American oncologists-hematologists (D. Pinkel, J. Simone, 1970, R. J. A. Aur, 1971), who in the last century successfully used in clinical practice the program of so-called "total therapy" in children [11-12]. The use of these programs in the pathogenetic and symptomatic treatment of patients with acute leukemia allowed further specialists of the St. Jude hospital (St. Jude Children's Research Hospital, Memphis, USA) in 1979 to reach, and in the early 80-ies of the last century to cross the $50.0 \%$ threshold of survival of patients with acute forms of leukemia [13-15]. This was a significant achievement at that time in the development of Oncohematology. Acute leukemias from the category of fatal diseases of the human hematopoietic system gradually moved to the category of diseases that could be treated, and the percentage of 5-year survival rate of oncogematological patients has steadily increased with each decade.

Modern principles of treatment of acute leukemia are based on the following basic principles: duration and intensity of therapy at all stages of development of malignant pathology; strict compliance with the doses of antitumor drugs, depending on the type of therapy and the timing of their use in accordance with the treatment protocols; the combination of cytostatic drugs in order to synchronize their mechanism of action with the main phases of the mitotic cycle of development of leukemic cells, namely, the appointment of drugs characterized by different phase cyclospecificity with drugs that differ in non-cyclical mechanism of action. This contributes to the maximum coverage of a significant number of leukemic cells; compliance with cyclical and precyclical use of antitumor drugs; timely elimination of side effects in the use of cytostatic drugs by prescribing a complex of antifungal and antimicrobial drugs [16-19]. In general, it should be noted that in the treatment of acute leukemia, a whole range of methods are used, namely chemotherapy, symptomatic, substitution, paliative, radiation therapy, as well as bone marrow transplantation. At the same time, the use of chemotherapy for a long time, as well as the relief of side effects of cytostatic drugs requires significant financial resources $[10,11,18]$. The limited nature of resources in the health care system may put forward the question on the process of achieving maximum therapeutic effect in the treatment of patients with acute leukemia, in particular myeloid leukemia. This problem can be solved by applying methods of pharmacoeconomical analysis, which has recently become increasingly important in various fields of practical medicine, including in Oncohematology [20]. 
This statement allowed us to formulate the main goal of our research.

\section{Purpose of the study}

The objective of this study is the pharmacoeconomical research of the rationality of using various chemotherapy regimens ("7+3" scheme) in the treatment of patients with acute forms of myeloid leukemia.

\section{Materials and methods}

In the study, we used the method of cost-effectiveness analysis (CEA). We calculated the value of the CEA indicator and the incremental cost - effectiveness ratio (ICER), which expresses the value of the additional amount that have to be spent to achieve an additional unit of effectiveness when using a more effective and more costly treatment method instead of another. To assess the rationality of using certain doses of anticancer drugs from the group of antimetabolics and anthracycline antibiotics, we used the data of multicenter randomized studies of chemotherapy of myeloid acute leukemia, which had been carried out by Russian scientists [13]. The purpose of these studies was to analyze the effectiveness of the use of the so-called "large" and "small" doses of antimetabolites (cytarabine drug) to achieve stable induction / consolidation in the first line of chemotherapy for acute forms of myeloid leukemia. There were analysed 145 oncohematological patients of 18 hematological centers from 15 cities of the Russian Federation for 1.5 years in this study. Two groups of patients were prescribed two courses of chemotherapy "7 + 3" using high doses of daunorubicin, $60 \mathrm{mg} / \mathrm{m}^{2}$ per injection against the background of continuous infusion of cytarabine on the 2nd course of treatment at a dose of 100 and $200 \mathrm{mg} / \mathrm{m}^{2} /$ day on the 1-7th day. The total interval between courses of chemotherapy depended on the degree of cytopenia and averaged about 10-15 days.

In our pharmacoeconomic studies, as a unit of effectiveness, we took the indicators of achieving complete remission in patients (\%) while using the remission induction regimens after chemotherapy from the abovementioned studies [13] The basic data is shown in Table I. As one can see, the first group of patients used cytarabine preparations at a dose of $100 \mathrm{mg} / \mathrm{m}^{2}$, and the second, respectively, at a dose of $200 \mathrm{mg} / \mathrm{m}^{2}$ per day on the 1st-7th day, that is, twice more than first group. We calculated the total medical (direct and indirect) costs associated with the use of chemotherapy regimens for the specified group of oncohematological patients. To calculate the cost of the average daily dose of anticancer drugs, we calculated the values of the patient's body area $\left(\mathrm{m}^{2}\right)$, which corresponded to a person with a body weight of $70 \mathrm{~kg}$. In our calculations, we used the data of those trade names of anticancer drugs under the international non-proprietary names that had the lowest price characteristics.

All calculations had been carried out first in the Ukrainian national currency (UAH), and then they were converted into US $\$$ at the rate of the National Bank of Ukraine as of 01.01.2020 (1 US dollar $=23.68 \mathrm{UAH}$ ).
Table 1. Schemes of chemotherapy for acute forms of myeloid leukemia (scheme "7 + 3")

\begin{tabular}{|c|c|c|}
\hline & $\begin{array}{r}\text { Ap } \\
\text { chem } \\
\text { sch }\end{array}$ & $\begin{array}{l}\text { Analysed drugs, } \\
\text { taking into account } \\
\text { the form of release }\end{array}$ \\
\hline \multirow{2}{*}{$\begin{array}{l}\text { Patient group } \\
\text { No. } 1 \\
\text { (follow-up } \\
\text { period - } 1.5 \\
\text { years) }\end{array}$} & $\mathrm{mg} / \mathrm{m}^{2}$ & \multirow{2}{*}{$\begin{array}{l}\text { Daunorubicin lyophil. } \\
\text { powder for inj. } 20 \mathrm{mg} \\
\text { No. 1, Lens-Pharm } \\
\text { (Russia) }\end{array}$} \\
\hline & & \\
\hline \multirow{2}{*}{$\begin{array}{l}\text { Patient group } \\
\text { No. } 2 \\
\text { (follow-up } \\
\text { period - } 1.5 \\
\text { years) }\end{array}$} & $\begin{array}{r}\text { Daunorubi } \\
\mathrm{mg} / \mathrm{m}^{2} \mathrm{pe} \\
\text { day }\end{array}$ & \multirow{2}{*}{$\begin{array}{l}\text { Cytosar }{ }^{\circledR} \text { lyof. } \\
\text { powder for inj. sol. } \\
100 \mathrm{mg} \text { (fl.), with } \\
\text { solvent in amp. } 5 \mathrm{ml} \text {, } \\
\text { No. 1, "Pfizer Italia" } \\
\text { (Italy). }\end{array}$} \\
\hline & $\begin{array}{c}\text { Cytarabine }-200 \mathrm{mg} / \\
\mathrm{m}^{2} / \text { day }(1-7 \text { days })\end{array}$ & \\
\hline
\end{tabular}

In addition to the methods of pharmacoeconomic research, we also used general scientific (historical, logical, graphic, comparative, structural, etc.) and mathematical and statistical methods of analysis and scientific research. The statistical data processing had been carried out using the statistical package StatSoft. Inc. (2014), Statistica version 12.7 (May 2015) and Excel spreadsheet. After a preliminary assessment of the data, all indicators were imported into a Statistica 6.0 standard program for the applied statistical analysis. A pvalue $<0.05$ was considered statistically significant.

\section{Results and discussion}

As a result of pharmacoeconomical research, we determined the value of the ratio of total medical expenses when using remission induction schemes of the first line of chemotherapy to the effectiveness of its use in two groups of patients with acute myeloid leukemia. The results of the research are reflected in Table 2.

In the first group of patients, the indicator of total medical expenses was US \$831.48, and in the second group-US \$ 1278.28. Thus, the use of the "7+3" scheme in patients with acute myeloid leukemia in a higher dosage of citarabine was 1.5 times more expensive than when using this scheme in the group of patients \#1. At the same time, the indicator of clinical effectiveness in the second group of hematological patients was 1.6 times higher than in the case of using citarabine at a dose of $100 \mathrm{mg} / \mathrm{m}^{2} /$ day on day $1-7$.

Thus, when calculating the CEA index in the first group of patients, the result was 20.18 US \$/per unit of clinical effectiveness (achieving complete remission in patients, in\%), which is $5.0 \%$ more than when using the "7+3" scheme with a higher $\left(200 \mathrm{mg} / \mathrm{m}^{2} /\right.$ day on day $\left.1-7\right)$ dosage of citarabine drugs. Thus, among the chemotherapy schemes there were no dominant methods in the organization of the treatment process. Then we calculated the value of the ICER indicator. The value of the ICER indicator was 418.19 UAH / per unit of effectiveness or ICER=17.66 US $\$ /$ per unit of chemotherapy effectiveness. As we can see, despite the fact that the second group of patients used the "7+3" chemotherapeutic scheme, which contained citarabine at a dose that was twice higher than in the first group of patients, its use demonstrated higher indicators. That's why chemotherapeutic regimen used in second group is 
more effective from the position of rational use of resources.

Table 2. Results of pharmacoeconomical analysis " $7+3$ " in chemotherapy of patients with acute myeloid leukemia ("CostEffectiveness" Method")

\begin{tabular}{|c|c|c|c|c|}
\hline \multicolumn{5}{|c|}{$\begin{array}{l}\text { Data on the effectiveness of different chemotherapy } \\
\text { schemes and cost indicators associated with their use in } \\
\text { hospital settings }\end{array}$} \\
\hline \multirow{2}{*}{$\begin{array}{l}\text { Achieving } \\
\text { complete } \\
\text { remission, } \\
\text { (\% of } \\
\text { patients) } \\
13\end{array}$} & \multicolumn{2}{|c|}{$\begin{array}{c}\text { Total medical } \\
\text { expenses }\end{array}$} & \multicolumn{2}{|c|}{ CEA indicator } \\
\hline & UAH. & US \$ & $\begin{array}{c}\text { UAH/ } \\
\text { per unit } \\
\text { efficiency }\end{array}$ & $\begin{array}{c}\text { US \$/ } \\
\text { per unit } \\
\text { efficiency }\end{array}$ \\
\hline
\end{tabular}

Group of patients \#1: (scheme N1): daunorubicin $60 \mathrm{mg}$ $\mathrm{mg} / \mathrm{m}^{2}$ per day on the $1 \mathrm{st}-3 \mathrm{rd}$ day; citarabin -100 $\mathrm{mg} / \mathrm{m}^{2} /$ day on the $1 \mathrm{st}-7$ th day.

\begin{tabular}{|c|c|c|c|c|}
\hline 41,2 & 19689,45 & 831,48 & 477,86 & 20,18 \\
\hline
\end{tabular}

Group of patients \#2 (scheme N2): daunorubicin $60 \mathrm{mg}$ $\mathrm{mg} / \mathrm{m}^{2}$ per day on the $1 \mathrm{st}-3^{\text {rd }}$ day; citarabin $-200 \mathrm{mg} / \mathrm{m}^{2} /$ day on 1 st-7th day.

\begin{tabular}{|l|l|l|l|l|}
\hline 66,5 & 30269,67 & 1278,28 & 455,13 & 19,22 \\
\hline
\end{tabular}

At the same time, it should be noted that the use of the "7+3" chemotherapy regimen in the dosage of citarabine $200 \mathrm{mg} / \mathrm{m}^{2} /$ day on day $1 \mathrm{st}-7$ th requires more careful supervision over the development of side effects from the use of antitumor drugs in patients with acute myeloid leukemia $[6,8,13]$. In the case of severe cytopenia and fungal infections, the effectiveness of chemotherapy may be significantly lower than in the group of patients receiving chemotherapy with cytarabine at a dosage of $100 \mathrm{mg} / \mathrm{m}^{2} /$ day on day $1 \mathrm{st}-7 \mathrm{th}$.

\section{Conclusion}

Stating the results of pharmacoeconomical studies of the use of two chemotherapy regimens (scheme "7+3") for acute myeloid leukemia using different dosages of citarabine, we can claim the following. Using a chemotherapy regimen ("7+3") with a dosage of citarabine $200 \mathrm{mg} / \mathrm{m}^{2} /$ day on day $1 \mathrm{st}-7$ th in the second group of patients allows to achieve a unit of treatment effectiveness at a lower cost, compared to the group of patients who treated with citarabine at a dosage that was twice less $\left(100 \mathrm{mg} / \mathrm{m}^{2} /\right.$ day on day $\left.1-7\right)$. In the future, the presented research results can be used in the formation of programs for the rational use of limited health care resources in the purchase of anti-cancer drugs for oncohematological patients, as well as in the development of schemes for providing effective medical care to these groups of cancer patients. There is no doubt that the results of pharmacoeconomical studies of the rationality of using various chemotherapy regimens should be of priority importance in the implementation of the above measures.

\section{References}

1. H. Döhner, D.J. Weisdorf, C.D. Bloomfield, N. Engl. J. Med.,. 373, p. 1136-1152 (2015)
2. F. L. Mabrey, K. M. Gardner, K. S. Dorcy, A. Perdue, H. A. Smith [et al.], Blood Adv., 4, 611-616 (2020)

3. Leunis, H.M. Blommestein, P.C. Huijgens, N.M. Blijlevens, M. Jongen-Lavrencic, C.A. Uyl-de Groo, Leuk. Res., 37, 245-250 (2013)

4. H. Döhner, E.H. Estey, S. Amadori, [et al.], Blood, 115, , p. 453-474 (2010)

5. F.R. Appelbaum, H. Gundacker, D.R. Head, [et al.], "Age and acute myeloid leukemia," Blood., 107, p. 3481-3485 (2006)

6. F. Efficace, G. Kemmler, M. Vignetti, F. Mandelli, S. Molica, B. Holzner, Eur. J. Cancer, 44, p. 149715069 (2008)

7. J.-Y. Cahn, M. Labopin, J. Sierra, D. Blaise, J. Reiffers, A. Ferrant [et al.], British Journal of Haematology, 110, p. 308-314 (2000)

8. S.-Ch. Heng, M. A. Slavin, D. Al-Badriyeh, S. Kirsa, J. F. Seymour [et al.], J. Antimicrob. Chemother., 68, 1669-1678 (2013)

9. G.J. Roboz, Novel approaches to the treatment of acute myeloid leukemia,: Hematology (Eduacation program book , San Diego), 43-50 (2011)

10. R.B. Walter, L.R. Taylor, K.M. Gardner, K.S. Dorcy, J.E. Vaughn, E.H. Estey, Clin Adv Hematol Oncol., 11. 571-577, (2013).

11. A.M. Stalfelt, H. Brodin, B. Wadman, Leuk. Res., 18, 783-790 (1994)

12. M.L. Savoie, T.J. Nevil, K.W. Song [et al.], Ann Oncol., 17, 763-768, (2006)

13. E.N. Parovichnikova, G.A. Klyasova, A.N. Sokolov [et al.], Therapeutic archive, 7, 10-15, (2012).

14. H.F. Fernandez, Z. Sun, X. Yao [et al.], N. Engl. J. Med., 361, 1249-1259, (2009)

15. T. Møller, O.J. Nielsen, P. Welinder [et al.], Eur. J Haematol., 84, 316-322 (2010)

16. O.A. Cornely, A. Bohme, D. Buchheidt [et al.], Haematologica, 94, 113-122, (2009)

17. T. Buchner, W.E. Berdel, C. Schoch [et al.], J. Clin. Oncol., 24, 2480-2489, (2006)

18. R.B. Walter, M. Othus, G. Borthakur [et al.], J. Clin. Oncol., 33, p. 4417-4423 (2011)

19. J. Crawford, D.C. Dale, N.M. Kuderer [et al.], J. Natl. Compr. Canc. Netw., 6, 109-118. (2008)

20. I.V. Spichak, Y.S. Dereglazova, A.S. Spichak [et al.], ," Drug Invention Today, 11, 2395-2399, (2019) 